\title{
Bapedi phytomedicine and their use in the treatment of sexually transmitted infections in Limpopo Province, South Africa
}

\author{
Sebua Silas Semenya ${ }^{1 \star}$, Marthienus Johannes Potgieter ${ }^{1}$ and Lourens Johannes Christoffel \\ Erasmus $^{2}$
}

${ }^{1}$ Department of Biodiversity, School of Molecular and Life Sciences, University of Limpopo, Private Bag X1106, Sovenga 0727, South Africa.

${ }^{2}$ Department of Physiology and Environmental Health, School of Molecular and Life Sciences, University of Limpopo, Private Bag X1106, Sovenga 0727, South Africa.

Accepted 18 January, 2013

Thirty four traditional healers from 17 municipalities, covering three districts of the Limpopo Province, were interviewed during the first half of 2011. Fourty seven plant species belonging to 32 families, mostly from the Asteraceae (9\%), Asphodelaceae, Fabaceae and Hyacinthaceae (6\% for each) were used to treat sexually transmitted infections (STIs) such as gonorrhoea, HIV/AIDS, nta (unspecified verneral disease - Bapedi terminology) and syphilis. Eighty seven percent of the species were used to treat a single STI, with the remainder being used to treat two STIs. Double-used species include: Aloe marlothii (gonorrhoea and chlamydia), Callilepis salicifolia (gonorrhoea and HIV/AIDS), Cucumis myriocarpus (gonorrhoea and syphilis), Drimia elata (gonorrhoea and HIV/AIDS), Hypoxis hemerocallidea (gonorrhoea and HIV/AIDS) and Ziziphus mucronata (gonorrhoea and nta). Diagnosis of STIs by Bapedi traditional healers is based primarily on the presentation of symptoms and certain behavioural traits, which are not always accurate indicators. The present study concludes that Bapedi traditional healers' knowledge can lead to useful medicinal plants to manage and treat STIs. Furthermore, given the necessary health information and support, these healers could play an important role in the management and treatment of STIs in the Limpopo Province.

Key words: Traditional healers, ethnobotany, medicinal plants, sexually transmitted infections

\section{INTRODUCTION}

Sexually transmitted infections (STIs) are a major public health concern in developing countries. According to World Health Organization (1991), Treponema pallidum, Neisseria gonorrhoeae, Chlamydia trachomatis and Trichomonas vaginalis are the parasitic pathogens responsible for most STIs. These infections respond well to treatment with antibiotics. However, globally, there are over 25 STIs, some of which have serious and permanent health problems when left untreated, while many facilitate the spread of HIV/AIDS infections

\footnotetext{
*Corresponding author. E-mail: Sebuasemenya@gmail.com.
}

(Paavonen, 2004).

In southern Africa, transmission rates are reaching epidemic proportions where STIs are currently one of the highest in the world (Van Vuuren and Naidoo, 2010). In South Africa, $26 \%$ of all deaths during the year 2000 were as a result of STIs (Johnson et al., 2000). Sexually transmitted infections are one of the most common reasons for people to visit traditional healers in South Africa. According to Msiska et al. (1997) rural patients are more dependent on traditional medicine from healers for STIs because of hesitancy to relate this form of illness to unknown doctors and being examined by a member of the opposite sex in western treatments. A survey by Peltzer (2003) found that among rural adult South 
Africans who had STIs in the past 12 months, 36\% did consult a traditional healer for treatment.

These healers do not have access to laboratory services and rely on the presence of symptoms and certain behavioural traits to assist them in their diagnosis of STIs (Kambizi and Afolayan, 2001). In cases of symptomatic presentation the occurrence of one or more of the following forms part of the WHO syndromic management guidelines: Abnormal urethral discharge, dysuria or ulcers in the genital area (Johnson et al., 2011). These guidelines aim to treat STI patients according to their symptoms, are in line with the approach followed by traditional healers.

Traditional healers use medicinal plants as their primary source of medicine to treat STIs. Significant literature exists in support of herbal remedies being used to treat STIs by traditional healers of different cultures in Africa (Ndubani and Hojer, 1999; Kambizi and Afolayan, 2001; Chigora et al., 2007; Ssegawa and Kasenene, 2007; Kamatenesi-Mugisha et al., 2008; Kayode and Kayode, 2008; Njoroge and Bussmann, 2009; Hossan et al., 2010; Chinsembu and Hedimbi, 2010; Namukobe et al., 2011; Maroyi, 2011; Muthee et al., 2011). South Africa is no exception and studies such as Samie et al. (2005); Tshikalange et al. (2005); Amusan et al. (2005); Mulaudzi et al. (2011); De Wet et al. (2012) highlight this. The extensive documentation of the plant use by a significant number of cultures around the world has led to extensive knowledge of the used plants' chemistry and pharmacological effects (Alam et al., 2012; Asgarpanah and Ramezanloo, 2012; Nasri et al., 2012). It is thus unfortunate that one of the great ethnic groups in South Africa, the Bapedi, has received no attention regarding their materia medica for STIs. The aim of this study was to document medicinal plants used by Bapedi traditional healers to treat STIs in the Limpopo Province, South Africa.

\section{MATERIALS AND METHODS}

\section{The study area and population}

The present study was carried out in 17 local municipalities (Table 1) of the Limpopo Province, covering the three of the five districts (Capricorn, Sekhukhune and Waterberg) that constitute the Limpopo province (Figure 1). The vegetation in these districts was classified by Acocks (1988) as arid-semi savannas. It is characterized by a mixture of trees, shrubs and grasses (Mucina and Rutherford, 2006). This type of vegetation has provided a diverse flora with rich medicinal plants that the people of the study areas have always used to treat many illnesses.

The surveyed districts are inhabited by Black people mostly from the Bapedi, Vhavenda and VhaTsonga ethnic groups, as well as coloured (mixed-race group) and white people. The Bapedi ethnic group constitutes the largest cultural group in the Limpopo Province (South Africa), comprising $57 \%$ of the total provincial population (Limpopo Provincial Government, 2012). This ethnic group use herbal medications either alone or in combination with orthodox medicines for the treatment of several diseases (Semenya et al., 2012). Majority of the Bapedi people in the studied districts are rural dwellers, hence the use of plants for the treatment of common diseases, such as STIs which is very prevalent.

\section{Ethnobotanical survey}

A reconnaissance survey was done in each local municipality to: (i) obtain permission to conduct this study within their area of jurisdiction, and (ii) to meet with the traditional healers to request them to participate in the study. Information was collected from January 2011 to July 2011. Semi-structured interviewees, observation and guided field walks with traditional healers were employed to obtain ethnobotanical data.

Semi-structured questionnaires were completed by 34 traditional healers from 17 local municipalities. In each local municipality two traditional healers were randomly selected and the objective of the study was explained in Sepedi, the local language. Interviews were designed to gather data on the plants used to treat STIs, methods of preparation, administration of medicine and diagnoses of STIs. Field observations were made on the morphological features and habitats of each medicinal plant species in the field. Based on ethnobotanical information provided by traditional healers, specimens were collected, numbered, pressed and dried for identification at the University of Limpopo's Larry Leach Herbarium.

\section{Data analysis}

The recorded data were organised and analysed for descriptive statistical patterns with Microsoft Excel spreadsheet software. Descriptive statistics, such as percentages and frequencies, have been used to analyse the data obtained from the questionnaires.

\section{RESULTS}

\section{Sexually transmitted infection identification}

Five seemingly different STIs are treated by Bapedi traditional healers. These include gonorrhoea, chlamydia, HIV/AIDS, nta and syphilis. Not all of these STIs are treated by all the healers. In fact none of the traditional healers from a single municipality indicated that they treat all five-listed STIs. For example, two traditional healers from the Elias Motsoaledi municipality treat four of the five STIs, the exclusion being syphilis. Traditional healers from the Capricorn district treated only gonorrhoea and chlamydia; whilst those from the Sekhukhune district treat all the infections among them, and in the Waterberg district the focus was on chlamydia, gonorrhoea and HIV/AIDS.

Among the three districts general consensus regarding the presentation and identification of gonorrhoea was reached. All traditional healers agreed that behaviour such as unprotected sexual intercourse with many partners or an infected partner will result in being infected. The only symptomatic presentation used during the diagnosis was the presence of a smelly urethral discharge.

None of the healers from the Capricorn district treated HIV/AIDS. Therefore information regarding this disease was obtained only from Sekhukhune and Waterberg districts. Only one traditional healer (Modimolle municipa- 
Table 1. Districts and local municipalities included in this study.

\begin{tabular}{llllll}
\hline Capricorn district & \multicolumn{2}{l}{ Sekhukhune district } & \multicolumn{2}{l}{ Waterberg district } \\
\hline Aganang & A & Elias Motsoaledi & F & Bela-Bela & L \\
Blouberg & B & Fetakgomo & G & Lephalale & M \\
Lepelle-Nkumpi & C & Groblersdal & H & Modimolle & N \\
Molemole & D & Makhuduthamaga & I & Mogalakwena & O \\
Polokwane & E & Marble Hall & J & Mookgophong & P \\
& & Tubatse & K & Thabazimbi & Q \\
\hline
\end{tabular}

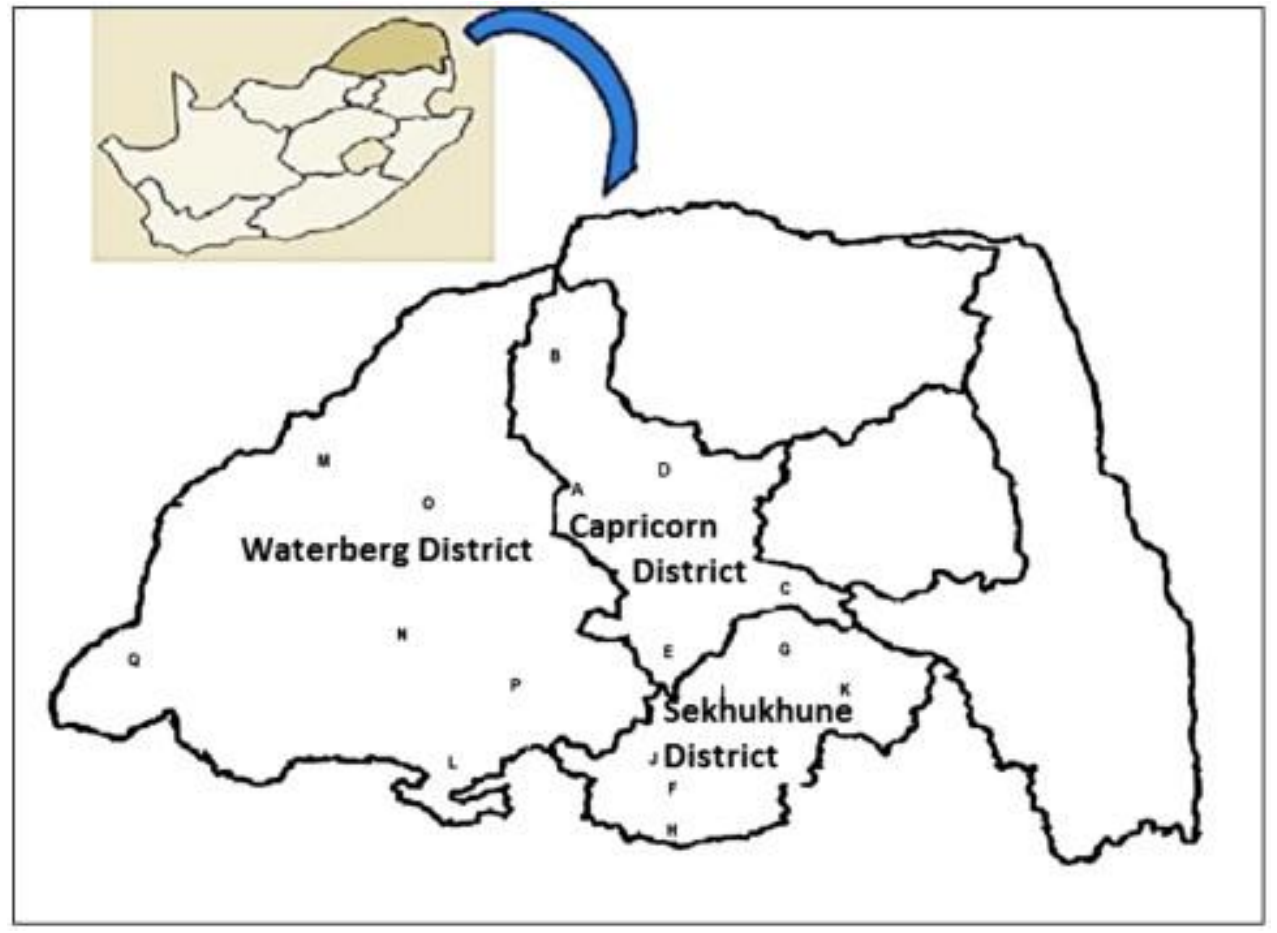

Figure 1. Study area: Capricorn, Waterberg and Sekhukhune districts, Limpopo Province, South Africa. A to $Q$ designates the involved municipalities.

lity) indicated exposure to contaminated blood as a source of infection. The remainder identified sexual intercourse with the partner of a person who died from HIV/AIDS as the leading cause of contracting this disease. Overwhelming support was observed for the occurrence of sudden and dramatic weight loss, which was, according to the healers, positively associated with HIV/AIDS.

Chlamydia was only treated by traditional healers from five local municipalities (Blouberg, Lepelle-Nkumpi, Polokwane, Elias Motsoaledi and Lephalale). General agreement has it that sexual intercourse with either a menstruating woman or a woman pregnant with another mans' child will result in contracting this disease. These patients have an abnormal gait and an inability to urinate.

Information regarding the identification of $n$ ta is lacking as only one traditional healer from the Elias Motsoaledi municipality treats it. Unprotected sexual intercourse with many partners was given as the reason for infection. A similar situation occurred regarding syphilis. Only one traditional healer from the Groblersdal municipality treats this disease. Once again unprotected sexual intercourse with many partners was a key factor in identification of the disease. However, this behavioural trait was complemented by the presence of a measle-like rash on the genitals.

\section{Plants used to treat sexually transmitted infections}

Bapedi traditional healers used 47 species of plants to treat chlamydia, gonorrhoea, HIV/AIDS, nta and syphilis (Table 2). These species belong to 43 genera and 32 families. The most representative families were Asteraceae (9\%) followed by the Asphodelaceae, Fabaceae and Hyacinthaceae (6\% each). 
Table 2. Species and parts: Extract preparation, administration and dosages used by Bapedi traditional healers to treat sexually transmitted infections.

\begin{tabular}{|c|c|c|c|c|c|c|c|}
\hline Species name & $\begin{array}{l}\text { Voucher } \\
\text { numbers }\end{array}$ & $\begin{array}{l}\text { Botanical } \\
\text { Family }\end{array}$ & Vernacular name & $\begin{array}{l}\text { Used } \\
\text { part/s }\end{array}$ & Preparation, dosage and administration & $\begin{array}{l}\text { STls } \\
\text { treated }\end{array}$ & $\begin{array}{l}\text { Citation } \\
\text { No. }(\%)\end{array}$ \\
\hline Aloe arborescens Mill. & SS 59 & Asphodelaceae & Kgopha-ya-fase & Root & Boiled for 20 minutes and one tin cup of the extract taken orally. Thrice a day & HIVIAIDS & $3 \%$ \\
\hline Aloe falcata Baker & SS 330 & Asphodelaceae & Kgopha & Root & $\begin{array}{l}\text { Mixed with E. crispa (root) and boiled for } 20 \text { minutes. One tin cup of the extract taken orally. Thrice a } \\
\text { day }\end{array}$ & HIVIAIDS & $3 \%$ \\
\hline \multirow[b]{2}{*}{$\begin{array}{l}\text { Aloe marlothii A. Berger subsp. } \\
\text { marlothii }\end{array}$} & \multirow[b]{2}{*}{ SS 80} & \multirow[b]{2}{*}{ Asphodelaceae } & \multirow[b]{2}{*}{ Kgopha-ya-go-ema } & Root & $\begin{array}{l}\text { Boiled singly for } 20 \text { minutes or mixed with } D \text {. sylvatica (bulb) and boiled for } 20 \text { minutes. One tin cup of } \\
\text { either extract taken orally. Thrice a day }\end{array}$ & Gonorrhoea & \multirow[b]{2}{*}{$24 \%$} \\
\hline & & & & $\begin{array}{l}\text { Root \& } \\
\text { leaf }\end{array}$ & Mixed and boiled for 15 minutes. One tin cup of the extract taken orally. Thrice a day & Chlamydia & \\
\hline $\begin{array}{l}\text { Alternanthera pungens } \\
\text { Kunth }\end{array}$ & SS 402 & Amaranthaceae & Mosweetswe & Tuber & Macerated in cow's milk for 24 hours and one tin cup of the decoction taken orally. Thrice day & Gonorrhoea & $3 \%$ \\
\hline $\begin{array}{l}\text { Boscia albitrunca (Burch.) Gilg \& } \\
\text { Gilg-Ben. }\end{array}$ & SS 300 & Capparaceae & Mohlophi & Root & $\begin{array}{l}\text { Mixed with E. elephantina (root), P. ciliatus (root) and P. africanum (root). Boiled for } 20 \text { minutes and } \\
\text { one tin cup of the extract taken orally. Thrice a day }\end{array}$ & HIVIAIDS & $3 \%$ \\
\hline Burkea africana Hook. & SS 60 & Leguminosae & Monatlo & Root & $\begin{array}{l}\text { Mixed with C. verum (root), H. hemerocallidea (tuber) and G. aspera (entire plant). Boiled for } 20 \\
\text { minutes. One tin cup of the extract taken orally. Thrice a day }\end{array}$ & HIVIAIDS & $3 \%$ \\
\hline $\begin{array}{l}\text { Caesalpinia decapetala } \\
\text { (Roth) Alston. }\end{array}$ & SS 74 & Fabaceae & Mokgabane & Root & Boiled for 10 minutes and one tin cup of the extract taken orally. Thrice a day & Gonorrhoea & $3 \%$ \\
\hline Carica papaya L. & SS 70 & Caricaceae & Mophopho "wapoo" & Root & $\begin{array}{l}\text { Mixed with C. myriocarpus (tuber) and boiled for } 20 \text { minutes. One tin cup of the extract taken orally. } \\
\text { Thrice a day }\end{array}$ & Gonorrhoea & $3 \%$ \\
\hline Catharanthus roseus (L.) G. Don & SS 33 & Apocynaceae & $\begin{array}{l}\text { Lepolomo-le-le- } \\
\text { pinki-la drop }\end{array}$ & Root & Boiled for 5-20 minutes and one tin cup of the extract taken orally. Thrice a day & Gonorrhoea & $82 \%$ \\
\hline $\begin{array}{l}\text { Cinnamomum verum J. } \\
\text { Presl }\end{array}$ & SS 337 & Lauraceae & $\begin{array}{l}\text { Mokwere-kwere-o- } \\
\text { mogolo }\end{array}$ & Root & $\begin{array}{l}\text { Mixed with B. africana (root), H. hemerocallidea (tuber) and G. aspera (entire plant). Boiled for } 20 \\
\text { minutes and one tin cup of the extract taken orally. Thrice a day }\end{array}$ & HIVIAIDS & $3 \%$ \\
\hline $\begin{array}{l}\text { Citrullus lanatus (Thunb.) } \\
\text { Matsum. \& Nakai }\end{array}$ & SS 09 & Cucurbitaceae & Morotse & Root & $\begin{array}{l}\text { Mixed with } D \text {. viscose (root) and } E \text {. crispa (root). Boiled for } 20 \text { minutes and one tin cup of the extract } \\
\text { taken orally. Thrice a day }\end{array}$ & HIVIAIDS & $3 \%$ \\
\hline Cotyledon orbiculata L. & SS 37 & Grassulaceae & Tsebe ya kolobe & Root & $\begin{array}{l}\text { Boiled for } 20 \text { minutes and one tin cup of the extract taken orally. Thrice a day. } \\
\text { Macerated in warm water for } 24 \text { hours. One tin cup of decoction taken orally. Thrice a day }\end{array}$ & Gonorrhoea & $3 \%$ \\
\hline $\begin{array}{l}\text { Cucumis myriocarpus subsp. } \\
\text { leptodermis }\end{array}$ & SS 35 & Cucurbitaceae & Magapyana & Tuber & $\begin{array}{l}\text { Boiled for } 20 \text { minutes and one tin cup of the extract taken orally. Thrice a day } \\
\text { Mixed with C. papaya (root) and boiled for } 20 \text { minutes. One tin cup of the extract taken orally. Thrice a } \\
\text { day }\end{array}$ & $\begin{array}{l}\text { Syphilis } \\
\text { Gonorrhoea }\end{array}$ & $6 \%$ \\
\hline Dioscorea sylvatica var. brevipes. & SS 11 & Dioscoreaceae & Monamela & Bulb & $\begin{array}{l}\text { Mixed with A. marlothii (root) and boiled for } 20 \text { minutes. One tin cup of the extract taken orally. Thrice } \\
\text { a day }\end{array}$ & Gonorrhoea & $3 \%$ \\
\hline $\begin{array}{l}\text { Dodonaea viscose var. } \\
\text { angustifolia }\end{array}$ & SS 117 & Sapindaceae & Mofenshe & Root & $\begin{array}{l}\text { Mixed with C. lanatus (root), and E. crispa (root). Boiled for } 20 \text { minutes. One tin cup of the extract } \\
\text { taken orally. Thrice a day }\end{array}$ & HIVIAIDS & $3 \%$ \\
\hline $\begin{array}{l}\text { Elaeodendron transvaalense } \\
\text { (Burtt Davy) Rott. Archer }\end{array}$ & SS 32 & Celastraceae & Monamane & Root & $\begin{array}{l}\text { Mixed with D. elata (bulb), E. elephantina (root), S. birrea (bark), Z. capense (root) and S. viminale } \\
\text { (twigs). Boiled for } 20 \text { minutes and one tin cup of the extract taken orally. Thrice a day }\end{array}$ & HIVIAIDS & $3 \%$ \\
\hline
\end{tabular}


Table 2. Contd.

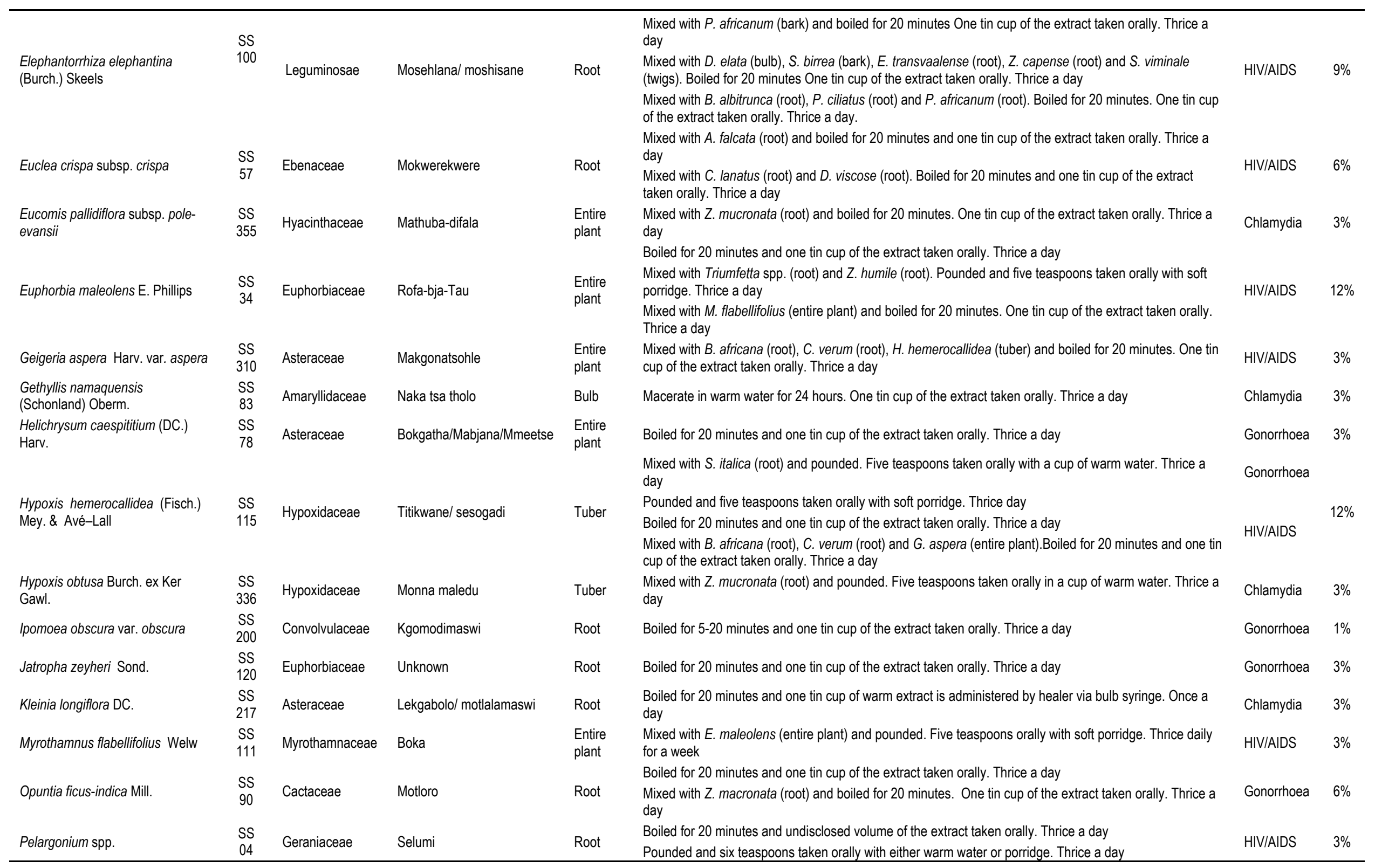


Table 2. Contd.

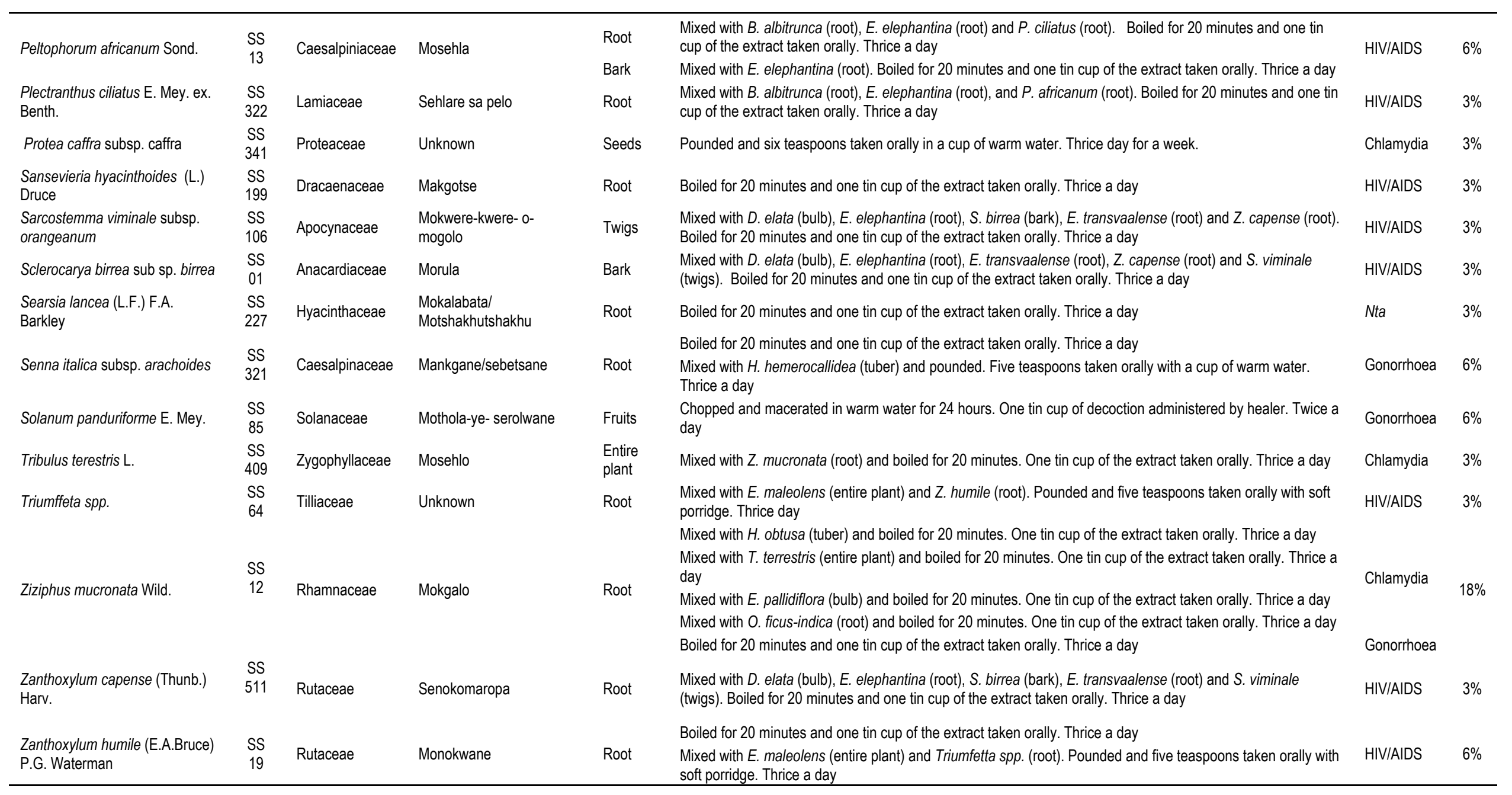

Table 2 indicate that 25 plant species are used to treat HIV/AIDS, 18 to treat gonorrhoea, eight to treat chlamydia, and one to treat nta and syphilis each. Twenty eight species were documented in the Waterberg district, 17 in the Sekhukhune district, and 12 in the Capricorn district. Eighty seven percent of the 47 recorded species are used to treat a single STI (Table 2), with just 13\% used to treat two STls, these include Aloe marlothiii (gonorrhoea and chlamydia), Callilepis salicifolia (gonorrhoea and HIV/AIDS), Cucumis myriocarpus subsp. leptodermis (gonorrhoea and syphilis), Drimia elata (gonorrhoea and HIV/AIDS), Hypoxis hemerocallidea (gonorrhoea and HIV/AIDS) and Ziziphus mucronata (gonorrhoea 
and nta). With the exception of Catharanthus roseus $(82 \%)$, used to treat gonorrhoea, no other species were used with the same consistency by traditional healers in the three districts.

\section{Plant parts used in remedy preparation}

Roots (58\%) were mostly used to prepare remedy for STIs, followed by entire plant (12\%), tuber (10\%), bulb $(6 \%)$, leaf and bark (4\% each), seed, twig and fruit $(2 \%$ each). When herbs are used to prepare remedies it is mostly their tubers or roots; however, in some cases the entire plant can be used. Roots are also the preferred plant part when shrubs are used to prepare herbal remedies. In rare cases the entire plant are used. It is notable that the roots are mostly used when plant material is collected from trees, with very little focus on bark, leaves, seeds or twigs. Bulbs and tubers are mostly obtained from perennial geophytes.

\section{Single vs. multiple plant extracts}

Twenty nine single plant extract and 40 multi plant extract preparations were recorded (Table 2). Nine plant species were used in single and multi-extract preparations. Among the multi extracts, $67 \%$ of healers employ two species, $13 \%$ three species, $13 \%$ four species and $7 \%$ six species. It is noteworthy that all extracts exceeding two species are used to treat HIV/AIDS. Twenty five of the 40 multi extract preparations are used to treat HIV/AIDS, seven to treat gonorrhoea and chlamydia.

\section{Preparation, administration and dosage of remedy}

Various preparation methods, such as boiling, pounding and maceration are used by Bapedi traditional healers. There is a clear preference for boiling, as almost $80 \%$ of all preparations are boiled. The boiling of plant materials ranges from 5 to 20 minutes (depending on an individual healer).

Often the traditional healers opted to pound (14\%) the plant material, whereas only a small number used maceration (6\%). These healers use either stones or crushing metals. Maceration is normally done over a period of 24 hours. The maceration medium might differ, as some healers use warm water whereas other healers use cow's milk at room temperature.

This study clearly illustrate that oral self-administration $(96 \%)$ is the method of choice. However, sometimes especially with rectal administration (enema) (4\%), via bulb syringe, the healers did the administration. Extracts are normally administered as a fluid, but in the event of pounded material either a fluid (water) or soft porridge can be used. Extracts are normally stored in $2 \mathrm{~L}$ plastic containers, and then consumed using a tin cup. In general one cup three times per day for a period of one week was adhered to. Powered medicines are stored in 400 gram containers, wrap in newspaper, cloth or plastic bags.

\section{DISCUSSION}

\section{Sexually transmitted infection identification}

As early as 1966, Bryant in his book on the materia medica of the Zulu tribe recorded an important phenomenon. He concluded that indigenous knowledge systems functioned on the premise that the symptoms equalled the ailment, and therefore focussed on symptomatic treatment rather than on the root cause of the symptoms. This is currently still the status quo as traditional healers treat symptoms, because asymptomatic people do not come for consultation.

With the exception of healers in two municipalities (Tubatse and Bela-Bela), all other healers treat gonorrhoea. Although $10 \quad(33 \%)$ traditional healers indicated that they use unprotected sexual intercourse with an infected person in combination with a smelly urethral discharge to identify gonorrhoea. Most traditional healers $(73 \%)$ rated unprotected sexual intercourse with multiple partners in combination with a smelly urethral discharge of greater importance in the identification process. The use of an abnormal urethral discharge concurs with the genital symptoms reported by Darj et al. (2010). Their study, focusing on the presentation of infected females at rural and urban clinics in Uganda, indicated that an abnormal vaginal discharge was the most prevalent symptom ( $75 \%$ urban vs. $84 \%$ rural), followed by genital itching and sores.

It is not surprising that unprotected sexual intercourse, either with an infected person or with multiple partners, formed part of the identification process as many initiatives in the media promote the use of condoms as a protective means. Unfortunately this study did not address the consistency of condom use or how many of the patients had multiple partners or an infected partner, as these aspects fell outside the scope. Sexual partnerships do have an impact on the spread of STIs such as gonorrhoea, syphilis (Kretzschmar and Morris, 1996) and HIV/AIDS (Morris and Kretzschmar, 1997).

Seventeen healers from 10 local municipalities treated HIV/AIDS. This in itself was surprising as one would have expected that of all the STIs treated, HIV/AIDS would have been the top priority as it is very prevalent in the studied areas (Igumbor et al., 2003). HIV/AIDS produces gradual effects on the human body's immune responses resulting in the development of cancers and opportunistic infections (Vermani and Garg, 2002). The list of symptoms associated with this disease is exhaustive, but the more prominent ones are persistent fever, night sweat, 
wasting syndrome, headache, skin rashes, diarrhoea, thrush, Kaposi's sarcoma, Candida esophagitis (KapusnikUner, 1996) and disseminated atypical mycobacterial infection (Murray and Pizzorno, 1999). Typically its identification, in this study was based on a combination of behavioural traits and accompanying symptoms. The behavioural aspects were straight forward and most traditional healers agreed that unprotected sexual intercourse with an infected person or the partner of a person who died of HIV/AIDS would increase the likelihood of being infected. The diagnostic criteria were a huge disappointment as weight loss (wasting syndrome) was the only consistent symptom used. This disappointment stems from the fact that so many symptoms exist that it is difficult to believe that the traditional healers would base the diagnosis of this dreadful disease on a single symptom, and the fact that weight loss can result from any number of conditions, including, but not limited to HIV/AIDS. One traditional healer from Modimolle municipality had a different approach to the identification of HIV/AIDS infection. He listed exposure to contaminated blood as the cause and excluded sexual activities as contributing factors. Wasting syndrome did not feature among the symptoms; however, his list included coloured ligaments (green), prolonged flu-like symptoms and a feeling of dizziness on hot days. It seems reasonable to say that the coloured ligaments and dizziness does not make sense, and that the prolonged flu-like symptoms can at least partially be accepted as one of the diagnostic criteria.

Chlamydia was less often treated and only five of the 17 municipalities had traditional healers who treated it. Why most of these traditional healers ( $3 / 5$ municipalities) reside in the Capricorn district is as yet not clear, and needs to be elucidated. Seven of the nine traditional healers who treated this disease mentioned that their patients had an abnormal gait ("stretch legs when walking") as well as an inability to urinate. Exposure to blood seems to play an important role in contracting this disease, as unprotected sexual intercourse with menstruating partners or one who just terminated her pregnancy was clearly indicated as a risk factor. This can lead to urogenital infections, which in turn can, to an extent, explain the inability to urinate. The phrase "stretch legs when walking" seems to be significant as $78 \%$ of the traditional healers referred to it exactly like this. The phenomenon itself needs further investigation.

$\mathrm{Nta}$ and syphilis were exclusively (indicating its prevalence in this district) treated by traditional healers from the Sekhukhune district. Nta was treated by traditional healers from the Elias Motsoaledi municipality, who used unprotected sexual intercourse with many partners as a means of identifying this ailment. No accompanying symptoms were recorded. The use of unprotected sexual intercourse for identification purposes is very vague as most of the other listed ailments also include it. Similar to this is a single traditional healer from the Groblersdal municipality who used unprotected sexual intercourse with many partners in his identification of syphilis. In addition to this it was mentioned that patients had many measles on their genitals. It is very difficult to say with certainty what is meant with "measles". The fact that it seems to be confined to the genital area creates more confusion. The only reasonable explanation is syphilis, as a skin rash does appear during the secondary stage (Jones and Lopez, 2006). This skin rash appears all over the body, is painless and does not itch. As a result of this, there is a possibility that both the traditional healers and patient could have overlooked it, simply because traditional healers, in the case of an STI, would not necessarily associate a rash on other body parts with an STI, and the patient, due to a lack of discomfort, might not mention it.

\section{Plant species used to treat sexually transmitted infections}

Bapedi traditional healers used 47 species of plants to treat chlamydia, gonorrhoea, HIV/AIDS, nta and syphilis. The presence of such a large number of plant species and their associated ethno medicinal knowledge indicates that the study area has a higher diversity of medicinal plants and that indigenous knowledge regarding STIs of traditional healers in this area compare favourably with findings of De Wet et al. (2012) in northern Maputaland, KwaZulu-Natal Province (South Africa).

The dominant families in this study were: Asteraceae (9\%), Asphodelaceae, Fabaceae and Hyacinthaceae (6\% each). Although not reported to exclusively treat STIs, these families are consistently recorded as mostly used in different ethno medicinal inventories. Species from the Asteraceae and Asphodelaceae families were dominant in a study conducted in the Agter-Hantam, Northern Cape Province (De Beer and Van Wyk, 2011). The Hyacinthaceae were also reported to be one of the most used plant families in the Eastern Cape Province (Koduru et al., 2007). However, a number of studies (Kambizi and Afolayan, 2001; Hossan et al., 2010) focussing on STIs reported the dominance of Fabaceae. These studies concluded that since the Fabaceae provided the highest number of species, it might be an important family for STIs and medicinal plants in general. The preference of the Asphodelaceae and Asteraceae families in this study could be attributed to their wide distribution range, large number of taxa and plant numbers (Thomas et al., 2009). According to Jones (1998) the wide use of Asteraceae in traditional medicine is linked to the wide range of biologically active compounds it contains. Heinrich et al. (1998) concluded that the widespread use of species from this family might be linked to the fact that it is one of the largest families in the plant kingdom.

With the exclusion of $n t a$ and syphilis, Bapedi traditional healers treated all STIs with more than one species. 
For instance HIV/AIDS was treated with 25 species, gonorrhoea with 18 species and chlamydia with eight. This ability to use many different species to treat a specific STI creates functional redundancy and facilitates resilience by increasing the likelihood for substitution if a particular plant is unavailable. Nevertheless, the high number plant species used by Bapedi traditional healers to treat HIV/AIDS was expected as currently there is no cure for this dreadful disease. These healers perhaps have been using plants for the symptoms but not the disease itself because it was unknown.

The majority of the plant species in this study was documented in the Waterberg district (28 spp.) and Sekhukhune district (17 spp.). Only 12 species was recorded in the Capricorn district. The degree of use could be linked to their distribution, abundance and/or intra cultural differences; an aspect that warrants further investigation.

Eighty seven percent of the 47 recorded species are used to treat a single STI (Table 2). The dominant use of a single species by Bapedi traditional healers perhaps has its advantages from a conservation point of view. This is because although the indigenous species are under threat, it is at least not under threat from being multi-used as well. However, Hossan et al. (2010) noted that using a variety of species against a particular ailment suggest that the disease is quite prevalent. In the current study $13 \%$ of species were used to treat two STIs, this includes $A$. marlothii (gonorrhoea and chlamydia), $C$. salicifolia (gonorrhoea and HIV/AIDS), C. myriocarpus (gonorrhoea and syphilis), D. elata (gonorrhoea and HIV/AIDS), $H$. hemerocallidea (gonorrhoea and HIV/AIDS) and Z. mucronata (gonorrhoea and $n t a$ ).

With the exception of $C$. roseus, used to treat gonorrhoea, no other species is used with the same consistency by traditional healers in the three districts. The reason for this is currently unknown; however, Van Wyk and Wink (2004) noted that one of the recognised evidences of efficacy and safety of an indigenous remedy is its widespread use for treating an ailment. Therefore, it is acceptable to postulate that $C$. roseus might be widely preferred by Bapedi traditional healers due to its efficacy against gonorrhoea. The use of this species to treat unspecified venereal diseases was previous reported for the Venda region, Limpopo Province, South Africa (Mabogo, 1990) and unspecified areas in Southern and Eastern Africa (Watt and Breyer-Brandwijk, 1962). Therefore, it might be possible that in the Venda region and Southern and Eastern Africa C. roseus is used for gonorrhoea. This is because venereal disease is a collective term for STIs.

Some medicinal species used by Bapedi traditional healers to treat STIs have been validated through scientific research or through their extensive use by various cultures in South Africa and other parts of Africa. For instance, the use of $T$. terrestris to treat chlamydia by Bapedi traditional healers is similar to that reported by
Mabogo (1990) in the Venda region. However, there is a difference between Vha-Venda and Bapedi with regard to the parts used. Bapedi healers prefer using the whole plant (flowers, fruit, stem, leaf and root), while Vha-Venda healers only use the leaves (Mabogo, 1990). Cultural and indigenous knowledge differences between Bapedi and Vha-Venda concerning the use of plant parts might have contributed to the observed variations.

Furthermore, Bapedi traditional healers use the root of C. papaya to treat gonorrhoea. A similar finding was previously reported for the Venda region (Arnold and Gulumian, 1984), and the northern Maputaland, KwaZulu-Natal Province of South Africa (De Wet et al., 2012). However, there are clear differences between Bapedi, Vha-Venda healers and lay people regarding the plant parts used. Bapedi and Vha-Venda prefer to orally prescribe extracts prepared from root, while lay people prefer to use extracts made from the leaves. Therefore, it can be argued that knowledge of its medicinal use varies according to geographical location. This is because both Bapedi and Vha-Venda healers inhabit the same area (Limpopo Province), while lay people (KwaZulu-Natal Province) are located some distance from both the Bapedi and Vha-Venda. In other parts of Africa leaves of $C$. papaya are commonly the preferred part to treat unspecified STls (Abbiw, 1990; Ndubani and Hojer, 1999). These studies verify the use of this species by Bapedi traditional healers in the treatment of STIs. The use of $T$. terrestris by Bapedi traditional healers to treat STIs corresponds with findings of Mabogo (1990). This similarity is of significance, because identical species-use by different cultures may be a reliable indication of curative properties. T. terrestris demonstrated antibacterial activity against Enterococcus faecalis, Staphylococcus aureus, Escherichia coli and Pseudomonas aeruginosa (Al-Bayati and Al-Mola, 2008). The use of $\mathrm{H}$. hemerocallidea by Bapedi traditional healers to treat HIV/AIDS and gonorrhoea correspond with findings of Puranwasi (2006) and De Wet et al. (2012) who reported its use to treat HIV/AIDS by the Zulu people in northern Maputaland. Singh (1999) furthermore reported the extensive use of this species by Zulu traditional healers in the treatment of urinary infections caused by STIs. It is also interesting to note that pharmacological activities of extracts from this species resulted in the extraction of $\beta$-sitosterol and $\beta$-sitosterol glycoside, which showed a significant decrease in plasma viral loads and stabilized CD $-4^{+}$cell counts over a period of 40 months in HIV positive patients (Bouic et al., 1999). This finding supports the use of $H$. hemerocallidea by both Bapedi and Zulu healers to treat HIV/AIDS, as well as other South Africans (Babb et al., 2007) who use this species to manage this virus. Conservation measures should be taken as this species is nationally threatened (SANBI, 2001).

Ziziphus mucronata is used in this study to treat both chlamydia and gonorrhoea. Hutchings et al. (1996) 
reported its use by Zulu healers to treat gonorrhoea only. No South African literature could be located to support its use by Bapedi healers to treat chlamydia. Available South African literature indicates its use to treat infertility and nerve pains by Vha-Venda healers (Mabogo, 1990), diarrhoea by Xhosa healers (Appidi et al., 2008) and as medicine to bring a good relationship with ancestors by Zulu healers (Ndawonde, 2006). In other parts of Africa, $Z$. mucronata is widely used to treat oral infections (Gundidza, 1986; Runyoro et al., 2006; Tapsoba and Deschamps, 2006).

To the best of our knowledge $C$. decapetala (gonorrhoea), E. elephantina (HIV/AIDS), Z. mucronata (chlamydia), $A$. pungens (gonorrhoea), $B$. africana (HIV/AIDS), C. verum (HIV/AIDS), C. lanatus (HIV/AIDS), E. crispa (HIV/AIDS), E. maleolens (HIV/AIDS), G. aspera (HIV/AIDS), $P$. ciliatus (HIV/AIDS), $P$. caffra (chlamydia), S. lancea (Nta), S. viminale (HIV/AIDS), Z. capense (HIV/AIDS) and $Z$. humile (HIV/AIDS) are reported for the first time in the treatment of the investigated STIs. This survey has made a major contribution in the plant species used traditionally for the treatment of STIs in South Africa and worldwide. It also offers considerable opportunities for further scientific research.

\section{Plant parts used in remedy preparation}

Data from this study illustrates a preference for the use of roots $(58 \%)$ and entire plant $(12 \%)$. This finding is almost similar to that reported by De Wet et al. (2012) in northern Maputaland. They noted the dominant of roots $(25 \%)$, followed by leaves and whole plant $(18 \%)$ in the treatment of STIs. However, Hossan et al. (2010) reported the dominance of root and leaves in their study which was conducted in Bangladesh. The wide use of the roots by Bapedi traditional healers to prepare medicine is based on the perception that more healing power is stored in this part (Semenya et al., 2012). Furthermore, their extensive use of entire plants $(12 \%)$ was because they want to utilize all plant parts (roots parts, leaf and flower) concurrently. However, wide utilization of both roots and entire plant use has serious consequences from both ecological point of view and from the survival of the medicinal plant species as was observed in by Birhanu (2002) in Jabitehaan Wereda, West Gojam. Therefore, research should also be undertaken, to establish if substitute parts (such as leaves) have the same efficacy as other parts of the plant. It is reasonable to state that the limited use of seeds and fruits $(2 \%$ for each) by Bapedi healers might be due to their seasonal availability.

\section{Single vs. multiple plant extracts}

Forty preparations were drawn from mixtures of different species for the treatment of a single STI. For instance the root of $Z$. mucronata were mixed with either a bulb of $E$. pallidiflora or a tuber of $\mathrm{H}$. obtusa to treat chlamydia, or a root of $O$. ficus-indica to treat gonorrhoea. The practice of combing different species to treat a single STI was also reported by De Wet et al. (2012) for Zulu lay people. They found that 33 species are used in 23 different combinations of two or more species per herbal remedy for the treatment of a single STI. For example leaves of C. papaya were mixed with Senecio serratuloides (leaf) and a tuber of $H$. hemerocallidea to treat gonorrhoea. In the current study the combination of a root of $C$. papaya with a tuber of C. myriocarpus is a remedy for gonorrhoea. Bapedi healers indicated that they combine species to re-enforce the medicines and increase its efficacy. This observation is in agreement with the study by Mabogo (1990) for Vha-Venda traditional healers. It is interesting to note that pharmacological studies support this claim (Chow et al., 2003). This was further scientifically validated by Otieno et al. (2008), they evaluated this practice by mixing root extracts of Catha edulis, Eucomis natalensis, Harrisoni abyssinica and Ximenia caffra against single extracts of the same species. Multi-species extracts inhibited all tested bacterial species, while single extracts inhibited only three of them. Eight out of ten multi-species extracts were bactericidal, while only two out of four single extracts were bactericidal. Therefore it is reasonable to state that the Bapedi practice of combining medicinal species to treat a single STI might be effective.

Twenty nine single extract were used to treat one or more STls. For instance, A. marlothii is used to treat gonorrhoea, HIV/AIDS, and chlamydia by Bapedi healers in various surveyed areas, while species such as $H$. obtusa (chlamydia), S. hyacinthoides (HIV/AIDS) and Pelargonium species (HIV/AIDS) were exclusively used for a single STI (Table 2). The use of single species in the preparation of remedies was also reported by Fernandes et al. (2008) for the Venda region. For instance, $C$. roseus, $P$. africanum and $S$. panduriforme were amongst the species used by Venda healers to treat unspecified venereal diseases and infectious diseases (Fernandes et al., 2008). The preference of a single species by Bapedi healers in the preparation of extracts might be linked to their local availability. In the Southern Tigray, Northern Ethiopia, Giday and Gobana (2003) postulated that the wide utilization of a single plant species in the preparation of indigenous remedies by healers is ascribed to the differences in the socio-cultural landscapes, indigenous knowledge on synergetic effect of different medicinal plants and vegetation types. Saikia et al. (2006) reported that use of a single species in the preparation of an extract could be of great interest for the development of novel drugs as the exploration of therapeutic activity-bearing ingredients may be easier. However, the use of a single species by Bapedi healers in the preparation of extracts has both advantages and disadvantages from a conservation point of view. As 
noted earlier when used to treat a single STI it reduces harvesting pressure of being multi-used, likewise the opposite increases harvesting, thereby posing a threat.

\section{Preparation, administration and dosage of remedy}

Various preparation methods, such as boiling, pounding and maceration are used by Bapedi traditional healers. These are the most common methods of medicinal preparation used for STIs in South Africa (De Wet et al., 2012) and other African countries (Njoroge and Bussmann, 2009). Eighty percent of the plant material in this study was boiled in water. De Wet et al. (2012) and Njoroge and Bussmann (2009) also noted the preference for boiling material. This might be due to the simplicity of preparation. Some Bapedi healers (14\%) opted to pound dried plant materials. However, the low occurrence of pounding of medicinal material by Bapedi healers was expected as producing powders is a labour intensive process; the herbs must be cut into very small pieces, dried sufficiently to make them brittle, and then crushed intensively enough to reduce them to a reasonably fine powder. In central zone of Tigray, Northern Ethiopia, Yirga (2010) noted that the preference of pounding plant materials is driven by the scarcity of the plant in nature, and that healers preserve the plants that they could not easily find in communal areas. The same can be true with some of the threatened and declining (SANBI, 2001) species used by Bapedi healers. These species include $H$. hemerocalidea (declining) and E. maleolens (least concern), which were occasionally processed by pounding. The limited use of maceration, normally a 24hour procedure, as a preparation method by Bapedi healers might be due to its long preparation time.

Findings of this study illustrate that oral selfadministration (96\%) was the method of choice. Studies such as Kambizi and Afolayan (2001) and Chigora et al. (2007) also noted that most medicines used in the treatment of STIs are prescribed orally. The preference of this method by Bapedi traditional healers might be due to the fact that medication in liquid form is already dissolved, so it can readily be absorbed by the human body. Occasionally, Bapedi healers administered medication rectally $(6 \%)$ using a bulb-syringe; in such cases the traditional healers did the administration. The limited use of this method by Bapedi healers came as no surprise as they mentioned that it is very dangerous and mostly used by more experienced traditional healers. They agreed that incorrect dosages (too much) can be fatal.

Extracts are normally stored in $2 \mathrm{~L}$ plastic containers, and then consumed using a tin cup. In general one cup three times per day for a period of one week was adhered to; this is in line with the standard prescriptions in western medicine. However, traditional dosage remedies of Vha-Venda healers depend on the physical appearance of the patient and experience of individual healers (Mabogo, 1990). This finding was also reported in different parts of Ethiopia by studies such as Addis et al. (2001) and Teklehaymanot et al. (2008). The lack of use of standard/measured doses, and the large volumes of the doses used are difficult to manage. This may be dangerous as some of the species could have a high degree of toxicity, and overdose might cause serious health problems. It is interesting to note that Bapedi traditional remedies have precision with regard to dosage. This is because most of the remedies are prepared using similar species, method of preparation, administration and dosage (Table 2).

\section{Conclusion}

The present study revealed that Bapedi traditional healers possess a good knowledge of STIs identification. However, their diagnosis of STIs is based primarily on the presentation of symptoms, which is not always accurate. This is because some of the patients might have symptoms similar to STIs but are not necessarily infected; consequently traditional healers might prescribe incorrect and ineffective medication. However, given proper guidance and education, traditional healers could serve as an important source of information and can be incorporated in community-based STI prevention. The large number of species employed to treat STIs clearly reflects the diversity of treatment protocols used by Bapedi healers. In the treatment of the more prominent STIs, a number of alternative species can be used, which in itself will ensure that treatment options will always be available. Further studies to determine the efficacy of some of the recorded species against the reported STIs is strongly recommended.

\section{ACKNOWLEDGEMENTS}

The authors are grateful to the traditional healers in the Capricorn, Sekhukhune and Waterberg districts of the Limpopo Province, South Africa for sharing their knowledge on herbal medicine. The University of Limpopo is acknowledged for financial support.

\section{REFERENCES}

Acocks JHP (1988). Veld types of South Africa. $3^{\text {rd }}$ Edn. Memo. Bot. Surv. SA 57:1-146.

Abbiw DK (1990). Useful plants of Ghana. West African uses of wild and cultivated plants. Int. Technol. Pub., London and Royal Botanic Gardens, Kew. 337p.

Addis G, Abebe D, Urga K (2001). A survey of traditional medicinal plants in Shirka District, Arsi Zone, Ethiopia. Ethiop. Pharm. J. 19:3047.

Alam M, Anwar Sadat A, Muhammd N, Khan AA, Siddiqui BS (2012). Evaluation of Viburnum grandiflorum for its in-vitro pharmacological screening. Afr. J. Pharm. Pharmacol. 6(22):1606-1610.

Al-Bayati FA, Al-Mola HF (2008).Antibacterial and antifungal activities of different parts of Tribulus terrestris L. growing in Iraq.J. Zhejiang Univ. Sci. 9:154-159. 
Amusan OOG, Sukati NA, Dlamini PS, Sibandze FG (2005). Some Swazi phytomedicines and their constituents. Afr. J. Biotechnol. 6:267-272.

Appidi JR, Grierson DS, Afolayan AJ (2008). Ethnobotanical study of plants used for the treatment of diarrhoea in the Eastern Cape, South Africa. Park.J. Biol. Sci. 11: 1961-1963.

Arnold HJ, Gulumian M (1984).Pharmacopoeia of traditional medicine in Venda. J. Ethnopharmacol. 12:35-74.

Asgarpanah J, Ramezanloo F (2012). Chemistry, pharmacology and medicinal properties of Peganum harmala L. Afr. J. Pharm. Pharmacol. 6:1573-1580.

Babb DA, Pemba L, Seatlanyane P, Charalambous S, Churchyard GJ, Grant AD (2007). Use of traditional medicine by HIV-infected individuals in South Africa in the era of antiretroviral therapy. Psychol. Health Med. 12:314-320.

Birhanu A (2002). Use and Conservation of Human Traditional Medicinal Plants in Jabitehaan Wereda, West Gojam. M.Sc. Dissertation. Addis Ababa University, Ethiopia.

Bouic PJD, Clark A, Lamprecht J (1999). The effects of B-Sitosterol (BSS) and B-Sitosterol Glucoside (BSSG) mixture on selected immune parameters of marathon runners: Inhibition of Post Marathon Immune Suppression and Inflammation. Int. J. Sports Med. 20:258262.

Bryant AY (1996). Zulu Medicine and Medicine Men. Struik Publishers, Cape Town.

Chigora P, Masocha R, Mutenheri F (2007). The role of indigenous medicinal knowledge (IMK) in the treatment of ailments in rural Zimbabwe: The case of Mutirikwi Communal Lands. J. Sustain. Dev. Afr. 9:1509-1520.

Chinsembu KC, Hedimbi M (2010). An ethnobotanical survey of plants used to manage HIV/AIDS opportunistic infections in Katima Mulilo, Caprivi region, Namibia. J. Ethnobiol. Ethnomed.6:25. http://www.ethnobiomed.com/conte nt/6/1/25.Site accessed: 13 March 2012.

Chow KU, Nowak D, Boehrer S, Ruthardt M, Knau A, Hoelzer D, Mitrou PS, Weidmann E (2003). Synergistic effects of chemotherapeutic drugs in lymphoma cells are associated with down-regulation of inhibitor of apoptosis proteins (IAPs), prostate-apoptosis-responsegene 4 (Par-4), death-associated protein (Daxx) and with enforced caspase activation. Biochem. Pharmacol. 66:711-724.

Darj E, Mirembe FM, Råssjö EB (2010). STI-prevalence and differences in social background and sexual behaviour among urban and rural young women in Uganda. Sex. Reprod. Health care 1:111-115.

De Beer JJJ, Van Wyk BE (2011). An ethnobotanical survey of the Agter- Hantam, Northern Cape Province, South Africa.S. Afr. J. Bot. 77:741-754.

De Wet H, Nzama VN, Van Vuuren SF (2012). Medicinal plants used for the treatment of sexually transmitted infections by lay people in northern Maputaland, KwaZulu-Natal Province, South Africa. S. Afr. J. Bot. 78:12-20.

Fernandes I, Van Rensburg CEJ, Hoosen AA, Steenkamp V (2008).In vitro activity of medicinal plants of the Venda region, South Africa, against Trichomonas vaginalis.S. Afr. J. Epidemiol. Infect. 23:26-28.

Giday M, Gobana A (2010). An ethnobotanical survey on plants of veterinary importance in two woredas of Southern Tigray, Northern Ethiopia: SINET. Ethiop. J. Sci. 26:123-136.

Gundidza M (1986). Screening of extracts from Zimbabwean higher plants. Part II. Antifungal properties. Fitoterapia 57:111-113.

Heinrich M, Robles M, West JE (1998). Ortiz de Montellano, B.R. and Rodriguez, E., Ethnopharmacology of Mexican Asteraceae (Compositae). Ann. Rev. Pharmacol. Toxicol. 38:539-565.

Hossan MS, Hanif A, Agarwala B, Sarwar MS, Karim M, Rahman MT, Jahan R, Rahmatullah M (2010). Traditional use of medicinal plants in Bangladesh to treat urinary tract infections and sexually transmitted diseases. Ethnobot. Res. Appl. 8:61-74.

Hutchings A, Scott AH, Lewis G, Cunningham AB (1996).Zulu medicinal plants - An inventory. University of Natal Press, Pietermaritzburg.

Igumbor EU, Bradshaw D, Laubscher R (2003). Mortality profile from registered deaths for Limpopo Province, South Africa 1997-2001. South African Medical Research Council, Cape Town.

Johnson L, Bradshaw D, Dorrington R (2000). The burden of disease attributable to sexually transmitted infections in South Africa in 2000.
S. Afr. Med. J. 97:287-288.

Johnson LF, Dorrington RE, Bradshaw D, Coetzee DJ (2011). The effect of syndromic management interventions on the prevalence of sexually transmitted infections in South Africa. Sex. Reprod. Health care 2:13-20.

Jones JS (1998). Traditional healers are here to stay: Yes to traditional healers. S. Afr. Med. J. 88:1057-1060.

Jones RE, Lopez KH (2006). Sexually transmitted diseases. In: Jones, R.E. and Lopez, K.H. (eds). Human Reproductive Biology 3rd edition.Academic Press, Burlington, MA. pp. 496-499.

Kamatenesi-Mugisha $M$, Oryem-Origa $H$, Odyek $O$, Makawiti DW (2008). Medicinal plants used in the treatment of fungal and bacterial infections in and around Queen Elizabeth biosphere reserve, western Uganda. Afr. J. Ecol. 46:90-97.

Kambizi L, Afolayan AJ (2001). An ethnobotanical study of plants used for the treatment of sexually transmitted diseases (njovhera) in Guruve District, Zimbabwe. J. Ethnopharmacol. 77:5-9.

Kapusnik-Uner JE (1996). Human immunodeficiency virus (HIV) and acquired immunodeficiency syndrome (AIDS). In: Herfindal, ET, Gourley DR (eds). Textbook of Therapeutics - drug and disease management. Williams and Wilkins, Baltimore. pp.1405-1425.

Kayode J, Kayode GM (2008). Ethnomedicinal survey of botanicals used in treating sexually transmitted diseases in Ekiti State, Nigeria.Ethnobot. Leaflets 12:44-55.

Koduru S, Grierson DS, Afolayan AJ (2007). Ethnobotanical information of medicinal plants used for the treatment of cancer in the Eastern Cape Province, South Africa. Curr. Sci. 92:906-908.

Kretzschmar M, Morris M (1996). Measures of concurrency in networks and the spread of infectious diseases. Math. Biosci.133:165-195.

Limpopo Provincial Government (2012). The ethnic groups, languages and races. $\mathrm{Http}: / / \mathrm{www}$. Limpopo.gov.za/index.php?=com\&view=article\&id=3\&itemid=5. Site accessed: 13 March 2012.

Mabogo DEN (1990). The ethnobotany of the Vha-Venda. M.Sc. Dissertation. University of Pretoria, Pretoria.

Maroyi A (2011). An ethnobotanical survey of medicinal plants used by the people in Nhema communal area, Zimbabwe. J. Ethnopharmacol. 136:347-354.

Morris M, Kretzschmar M (1997). Concurrent partnerships and the spread of HIV. AIDS 11:641-648.

Msiska R, Nangawe E, Mulenga D, Sichome M, Kamanga J, Kwapa P (1997). Understanding layperspectives: Care options for STD treatment in Lusaka, Zambia. Health Pol. Plan. 12: 248-252.

Mucina L, Rutherford MC ( 2006). The vegetation of South Africa, Lesotho and Swaziland.Strelitzia 19. South African Biodiversity Institute. Pretoria.

Mulaudzi RB, Ndhlala AR, Kulkarni MG, Finnie JF, Van Staden J (2011). Antimicrobial properties and phenolic contents of medicinal plants used by the Venda people for conditions related to venereal diseases. J. Ethnopharmacol. 135:330-337.

Nasri S, Anoush M, Narges K (2012).Evaluation of analgesic and antiinflammatory effects of fresh onion juice in experimental animals. Afr J. Pharm. Pharmacol. 6:1679-1684.

Murray MT, Pizzorno JE (1999). Textbook of Natural Medicine. Churchill Living, China.

Muthee JK, Gakuya DW, Mbria JM, Kareru PG, Mulei CM, Njonge FK (2011). Ethnobotanical study of anthelmintic and other medicinal plants traditionally used in Loitoktok District of Kenya. J. Ethnopharmacol. 135:15-21.

Namukobe J, Kasenene JM, Kiremire BT, Byamukama R, KamatenesiMugisha M, Krief S, Dumontete V, Kabasa JD (2011). Traditional plants used for medicinal purposes by local communities around the Northern sector of Kibale National Park, Uganda. J. Ethnopharmacol. 136:236-245.

Ndawonde BG (2006). Medicinal plant sales: A case study in Northern Zululand. M.Sc. Dissertation. University of Zululand, Pietermaritzburg.

Ndubani P, Hojer B (1999). Traditional healers and the treatment of sexually transmitted illnesses in rural Zambia. J. Ethnopharmacol. $67: 15-25$

Njoroge GN, Bussmann RW (2009). Ethnotherapeutic management of sexually transmitted diseases (STDs) and reproductive health 
conditions in Central Province of Kenya. Indian J. Tradit. Know. 8: 255-261.

Otieno JN, Hosea KMM, Lyaruu HV, Mahunnah RLA (2008). Multi-plant or single-plant extract, which is the most effective for local healing in Tanzania? Afr. J. Tradit. Comp. Alt. Med. 5:165-172.

Paavonen J (2004). Sexually transmitted Chial mydical infections and subfertility. Int. Cong. Series. 1266:277-286.

Peltzer K (2003). HIV/AIDS/STD knowledge, attitudes, beliefs and behaviours in a rural South African adult population.S.Afr. J. Psychol. 33:250-260.

Puranwasi R (2006). The role of traditional healers in oral health care in KwaZulu-Natal.M.Sc. Dissertation.University of the Western Cape, Western Cape.

Runyoro DKB, Ngassapa OD, Matee MIN, Joseph CC, Moshi MJ (2006). Medicinal plants used by Tanzanian traditional healers in the management of Candidainfections. J. Ethnopharmacol. 106: 158165.

Saikia AP, Ryakala VK, Sharma P, Goswami P, Bora U (2006). Ethnobotany of medicinal plants used by Assamese people for various skin ailments and cosmetics. J. Ethnopharmacol. 106:149157.

Samie A, Obi CL, Bessong PO, Lall N (2005). Activity of fourteen selected medicinal plants from rural Venda communities in South Africa against fifteen clinical bacterial species. Afr. J. Biotechnol. 4:1443-1451.

Semenya S, Potgieter M, Erasmus L (2012). Ethnobotanical survey of medicinal plants used by Bapedi healers to treat diabetes mellitus in the Limpopo Province, South Africa. J. Ethnopharmacol. 141:440445.

Singh Y (1999). Hypoxis: Yellow stars of horticulture, folk remedies and conventional medicine. Veld and Flora. 85:123-125.

South Africa National Biodiversity Institute (SANBI) (2001). The IUCN Categories and Criteria version 3.1. SANBI, Pretoria.

Ssegawa P, Kasenene JM (2007). Medicinal plant diversity and uses in the Sango bay area, Southern Uganda. J. Ethnopharmacol. 113:521540.
Tapsoba H, Deschamps JP (2006). Use of medicinal plants for the treatment of oral diseases in Burkina Faso. J. Ethnopharmacol. 104:68-78.

Teklehaymanot T, Giday M, Medhin G, Mekonnen Y (2008). Knowledge and use of medicinal plants by people around Debre Libanos monastery in Ethiopia. J. Ethnopharmacol. 111:271-283.

Thomas E, Vandebroek I, Sanca S, Van Damme P (2009). Cultural significance of medicinal plant familie and species among the Quechua farmers in Apillampampa, Bolivia. J. Ethnopharmacol. 122:60-67.

Tshikalange TE, Meyer JJM, Hussein AA (2005). Antimicrobial activity, toxicity and the isolation of a bioactive compound from plants used to treat sexually transmitted diseases. J. Ethnopharmacol. 96:515-519.

Van Vuuren SF, Naidoo D (2010). An antimicrobial investigation of plants used traditionally in southern Africa to treat sexually transmitted infections. J. Ethnopharmacol. 130:552-558.

Van Wyk BE, Wink M (2004). Medicinal Plants of the World: An Illustrated Scientific Guide to Important Medicinal Plants and their Uses. Timber press, Portland, OR, USA.

Vermani K, Garg G (2002). Herbal medicine for sexually transmitted diseases and AIDS. J. Ethnopharmacol. 80:49-66.

Watt JM, Breyer-Brandwijk MG (1962). The Medicinal and Poisonous Plants of Southern and Eastern Africa. 2nd Ed. E. \& S. Livingstone, London.

World Health Organization (1991). Management of patients with sexually transmitted diseases. WHO Tech. Rep. Ser. pp.1-103.

Yirga $G$ (2010). Assessment of indigenous knowledge of medicinal plants in Central Zone of Tigray, Northern Ethiopia. Afr. J. Plant. Sci. 4:6-11. 